\title{
the Butterfly Effect: Coronavirus may Redefine the Global Currency Landscape
}

\author{
Shaoshan Liu \\ shaoshanliu@hks.harvard.edu \\ Harvard Kennedy School
}

In Trump's political viewpoint, all problems within the U.S. were caused by external problems, such as the rise of China, and thus Trump has rejected globalism and took on the policy of 'America First'. Trump's policy inevitably leads to the decoupling between the U.S. and China, and the recent coronavirus outbreak may catalyze the decoupling process. In short term, the U.S. fiscal and monetary rescue plans may expose the national debt and deficit problems, hurting foreign countries' confidence of the U.S. ability to pay its obligations. In long term, the U.S. has limited ability to stimulate economy without hurting the U.S. dollar's supremacy; whereas China has a greater ability to coordinate fiscal and monetary policies to stimulate economy. May the decoupling continues, the U.S.-China capital war becomes inevitable and it may redefine the global currency landscape.

\section{The Reasoning Template}

During the peak of the U.S.-China trade war, Ray Dalio warned that the global economy was facing three problems and a recession might be imminent ${ }^{1}$ : internally there is a large wealth gap and political polarity; externally there is a conflict between China as a rising power and the U.S. as an existing world power; and if there is an economic downturn, central banks have limited ability to stimulate. A lot has happened since then and we are now living in a completely different world. To make sense of the current situation, in the figure below, we construct a reasoning template with Dalio's arguments, the current U.S.-China conflict, the coronavirus outbreak, the upcoming U.S. presidential election, and the long-term anti-globalism policy. First, before the coronavirus outbreak, Trump already blamed globalism for causing the U.S. internal problems, and 'America First' is Trump's solution. Second, the global coronavirus outbreak unexpectedly triggers a global economic recession, which may worsen the increasing wealth gap and political polarity. Third, to avoid taking the blame for his own administration's struggles to deal with the virus, president Trump is actively blaming China for directly causing the outbreak, and indirectly causing the U.S. economic downturn. In summary, in Trump's viewpoint, all problems within the U.S. were caused by external problems, and thus a long-term solution is inevitably the U.S.-China decoupling. 


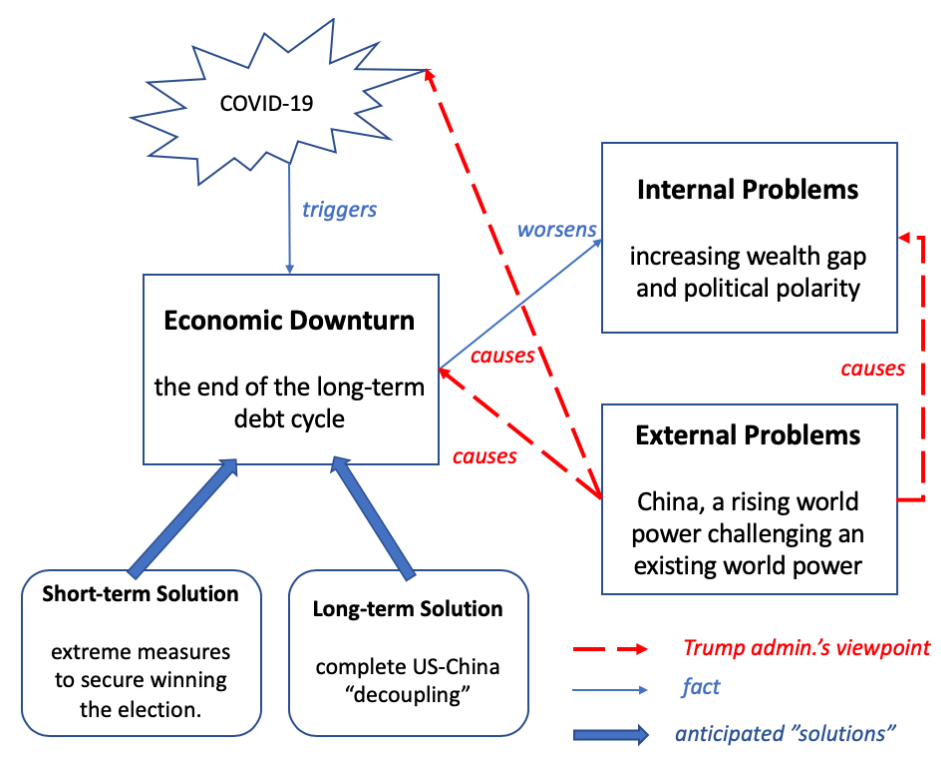

\section{The U.S. and China Conflict: More Than a Trade War}

President Trump believes that international collaboration has resulted in the U.S. being swindled. In Trump's viewpoint, for decades the U.S. opened its economy with few conditions, allowing foreign goods from all over the world to flow freely across U.S. borders, whereas other countries, such as China, did not grant that same access. Although a trade deal has been signed between the U.S. and China, the anti-China sentiment has only got worse. In a recent speech at the National Governors Association, Secretary of State Michael Pompeo delivered a stark message for the governors: the Chinese government is watching them, and other state government officials, more closely than they think. Pompeo also stressed that the U.S. demands reciprocity in all areas, not only in trade ${ }^{2}$. In addition, there has been an increasing tension between the U.S. and China on technology, a 2018 DIUX report indicates that Chinese participation in venture-backed startups is at a record level of 10-16\% of all venture deals between 2015 and 2017 and has grown quite rapidly in the past seven years. The technologies where China is investing are the same ones where U.S. firms are investing and that will be foundational to future innovation: artificial intelligence, autonomous vehicles, augmented/virtual reality, robotics and blockchain technology ${ }^{3}$. The conflict between the U.S. and China has started from a trade war, to a technology war, and if the U.S.-China decoupling continues, this conflict may soon escalate into a capital war which may threat the U.S. dollar's supremacy.

\section{Short-Term Election Rescue Plan}

The short-term goal of the Trump administration is crystal clear: to win the election in November. To achieve this goal, Trump needs to find a scapegoat for the widespread coronavirus and he needs to take extreme measures to stabilize the U.S. economy. Since early March 2020, attempting to deflect the blame from his administration to China, president Trump started calling the coronavirus the "Chinese" virus. This move successfully drove xenophobic sentiment towards China and avoided taking the blame for his own administration's struggles to deal with the virus. Sadly, this move also instigated a spike of in prejudice and discrimination against Asian- 
Americans. To stabilize the U.S. economy, the Fed has already taken some extreme measures, such as bluntly hitting the $0 \%$ interest rate floor. However, this move seemed ineffective. Recently, there is a $\$ 1$ trillion economic stabilization plan with corporate tax cuts and checks of up to $\$ 1,200$ for taxpayers. These moves are indicative that president Trump will do whatever it takes to stabilize the economy before the election. But these extreme moves will lead to a higher deficit and the national debt. In addition, the rescue plans may cause asset prices to rise and if compensation does not rise at the same rate, the wealth gap will widen. This may further lead to a conflict between socialists and capitalists, and the rise of populism and nationalism globally, which we have experienced before in the 1930 s depression ${ }^{4}$.

\section{Long-Term Decoupling}

In long term, the U.S. will face two imminent challenges: how to control the national debt and how to reduce wealth gap and political polarity, two rather contradictory goals. Before the coronavirus outbreak, it seems that the trade war hurt China more, as many U.S. companies are shifting supply chains, both in terms of production and sourcing, to other Asian countries. Meanwhile the U.S. was enjoying an economic boom and a low unemployment rate, which temporarily overshadowed the national debt problem. Now as the coronavirus outbreak hits the U.S., the Fed is running out of tools to stimulate the economy after hitting the $0 \%$ interest rate floor, and the current rescue plans will drastically increase the national debt. These events will hurt foreign countries' confidence of the U.S. ability to pay its obligations. One solution to the national debt problem under discussion is the Modern Money Theory (MMT), which monetizes the national debt and enables the government to guarantee full employment ${ }^{5}$. In an extreme situation that the U.S. adopts this policy, on the surface, the national debt and deficit problems are solved, however, the U.S. is an open instead of a closed economy, the adoption of MMT may completely destroy the U.S. dollar's status as a world reserve currency. China took a big hit in the current coronavirus outbreak too, but the Chinese government has a greater ability to coordinate fiscal and monetary policies, and China's central bank can still utilize monetary policy to stimulate the Chinese economy. In addition, in the past year, China's central bank has been preparing to test a digital currency, hoping to use the digital currency to challenge the supremacy of the U.S. dollar ${ }^{6}$.

\section{References}

1. https://www.linkedin.com/pulse/three-big-issues-1930s-analogue-ray-dalio/

2. https://www.youtube.com/watch? $=\mathrm{v} 1 \mathrm{~g} 1 \mathrm{BbswU} 3 \mathrm{i} 10$

3. https://admin.govexec.com/media/diux chinatechnologytransferstudy_jan_2018 (1).pdf

4. https://www.linkedin.com/pulse/paradigm-shifts-ray-dalio/

5. https://www.businessinsider.com/modern-monetary-theory-mmt-explained-aoc-2019-3

6. https://www.npr.org/2020/01/13/795988512/china-to-test-digital-currency-could-it-end-up-challenging-thedollar-globally 